\title{
Size, chlorophyll retention and protein and oil contents of grains from soybean plants grown in different spatial arrangements
}

\section{Tamanho, retenção de clorofila e teores de proteína e óleo de grãos de soja em diferentes arranjos espaciais}

\author{
Flávia Werner ${ }^{*}$; Alvadi Antonio Balbinot Junior ${ }^{2}$; \\ André Sampaio Ferreira ${ }^{1}$; Marcelo Augusto de Aguiar e Silva ${ }^{3}$; \\ José Marcos Gontijo Mandarino ${ }^{4}$; Claudemir Zucareli ${ }^{3}$
}

\begin{abstract}
The spatial arrangement of soybean plants, determined by row spacing and seeding rate, affects the intraspecific competition for water, light, and nutrients, as well as plant architecture and grain development, quality, and chemical composition. The aims of this study were to evaluate the effect of row spacing and seeding rate on the grain size produced, and the influence of these three factors on chlorophyll retention and protein and oil content in grain. Two experiments were conducted in the 2013/14 and 2014/15 growing seasons, using a $4 \times 3$ factorial randomized block design with three replications. Four different row spacings $[20 \mathrm{~cm}$ (narrow row), $50 \mathrm{~cm}$ (conventional), 20/80 cm (twin rows) and crossed lines $(50 \mathrm{~cm})]$ and three seeding rates $\left(150,300\right.$, and 450 thousand viable seeds ha $\left.{ }^{-1}\right)$ were evaluated. The grains were classified by size using oblong sieves and then the effects of spatial arrangements and size of grain on the percentage of green grains and protein and oil contents were evaluated. Higher plant densities were associated with larger grain size, whereas the effects of spacing between the rows on the grain size varied between growing seasons. The arrangement in cross-rows and high plant density produced a higher percentage of green grains under weather conditions favorable to the development of this attribute. The effects of plant spatial arrangements on the contents of protein and oil in grains were variable, and it was not possible to determine whether the spatial arrangement of plants had an effect on the levels of protein and oil in grains. Larger grains had higher protein content, but oil contents were not affected by grain size.
\end{abstract}

Key words: Glycine max L. Grain quality. Green grains. Row spacing. Seeding rate.

\section{Resumo}

O arranjo espacial de plantas de soja, determinado pelo espaçamento entre as fileiras e pela densidade de semeadura, afeta a competição intraespecífica por água, luz e nutrientes, bem como a arquitetura da planta, podendo influenciar na formação, qualidade e composição química dos grãos produzidos. Os objetivos do trabalho foram avaliar o efeito do espaçamento entre fileiras e da densidade de semeadura

${ }^{1}$ Eng $^{\text {os }}$ Agros $^{\text {, }}$, Mestres, Discentes do Curso de Doutorado em Fitotecnia, Universidade Estadual de Londrina, Centro de Ciências Agrárias, Departamento de Agronomia, UEL, Londrina, PR, Brasil. E-mail: flawerner6@gmail.com; andresampaioferreira@ gmail.com

${ }^{2}$ Eng $^{\circ}$ Agr $^{\circ}$, Dr., Pesquisador, Empresa Brasileira de Pesquisa Agropecuária, EMBRAPA Soja, Londrina, PR, Brasil. E-mail: alvadi.balbinot@embrapa.br

${ }^{3}$ Eng $^{\text {os }}$ Agros, Profs. Drs., Departamento de Agronomia UEL/CCA, Londrina, PR, Brasil. E-mail: aguiaresilva@uel.br; claudemircca@uel.br

${ }^{4}$ Farmacêutico-Bioquímico, M.e, Pesquisador, Empresa Brasileira de Pesquisa Agropecuária, EMBRAPA Soja, Londrina, PR, Brasil. E-mail: josemarcos.gontijo@embraba.br

* Author for correspondence 
no tamanho dos grãos produzidos e qual a influência desses três fatores na retenção de clorofila e nos teores de proteína e óleo nos grãos. Dois experimentos foram conduzidos nas safras 2013/14 e 2014/15, com delineamento de blocos casualizados, em esquema fatorial 4x3, com três repetições. Foram avaliados quatro espaçamentos entre fileiras: $20 \mathrm{~cm}$ (reduzido), $50 \mathrm{~cm}$ (convencional), 20/80 cm (fileira dupla) e $50 \mathrm{~cm}$ cruzado e três densidades de semeadura (150,300 e 450 mil sementes viáveis $\mathrm{ha}^{-1}$ ). Os grãos produzidos foram classificados em peneiras de crivos oblongos. Após, avaliaram-se os efeitos do arranjo espacial e do tamanho dos grãos sobre a porcentagem de grãos verdes e os teores de proteína e óleo. As maiores densidades de plantas possibilitam a formação de grãos com maior tamanho, enquanto os efeitos de espaçamentos entre as fileiras sobre o tamanho dos grãos são variáveis entre as safras. O arranjo em fileiras cruzadas e o aumento da densidade de plantas aumentam a porcentagem de grãos verdes em condições meteorológicas favoráveis à ocorrência desta característica. Os efeitos dos arranjos espaciais de plantas sobre os teores de proteína e óleo nos grãos são variáveis, não sendo possível indicar um arranjo espacial de plantas que possibilite incremento nos teores de proteína ou óleo nos grãos. Os grãos maiores apresentam teores de proteína superiores, mas os teores de óleo não são afetados pelo tamanho dos grãos.

Palavras-chave: Densidade de plantas. Espaçamento entre fileiras. Glycine Max L., Grãos verdes. Qualidade de grãos.

\section{Introduction}

Large-scale production of soybean (Glycine max (L.) Merril) is associated with complex systems of production, storage, processing, and trade (ZAKIR; FREITAS, 2015). The crop has high levels of protein; oil composed of saturated and polyunsaturated fatty acids; vitamins, mainly B-complex; P, K, Ca, Zn, and other minerals; and polyphenolic compounds such as isoflavones (ÁVILA et al., 2007; YIN; VYN, 2005). The main product obtained from soybean is protein meal, which is used as a feed for swine and poultry.

The spatial arrangement of plants, determined by sowing density and row spacing, may affect soybean production, due to modifications of the growth environment and plant development from sowing to harvest. Appropriate sowing density management affectsplant structural characteristics and may contribute to the control of weeds, pests, and diseases, as well as reducing lodging and maximizing yield (BALBINOT JR. et al., 2015; KHAN et al., 2003; PROCÓPIO et al., 2013; RIGSBY; BOARD, 2003). However, there is little information regarding the effects of sowing density and row spacing on the formation, quality, and composition of grains.

Soybean plant arrangement affects intraspecific competition for water, sunlight, and nutrients, which modifies environmental resources usage, thus affecting photoassimilate production (BOARD, 2000; BOROOMANDAM et al., 2009; KUSS et al., 2008). Stressful situations such as intense competition among plants, high temperatures, and dry periods during maturation may affect or even terminate chlorophyllase activity prior to complete chlorophyll degradation (RANGEL et al., 2011). The frequency of greenish soybeans in a batch is unstable and depends on the type, intensity, and period when stressful conditions occur (FRANÇA NETO et al., 2012).

Grain size may affect yield and oil and protein contents, which are important for human and animal consumption, and for biofuel production (MOURTZINIS et al., 2015). Oil and protein contents are affected by a cultivars intrinsic genetic factors, which may be mainly altered by environmental conditions during the soybean filling stage (ÁVILA et al., 2007; MINUZZI et al., 2009). Furthermore, the oil and protein content of soybeans may vary depending on location and crop management, like, plant spatial arrangement, which can modify plant structure and morphology (LUCA; HUNGRIA, 2014). However, few studies have evaluated the effects of interaction between sowing density and row spacing on soybean chemical composition (BELLALOUI et al., 2015; 
MOREIRA et al., 2015). Clarification of this issue is relevant for designing management techniques that simultaneously aim to achieve increased productivity and soybean quality with the lowest possible cost and environmental impact. In this context, spatial arrangement adjustment might constitute an important management technique for this purpose.

This then raises the following questions. Does higher sowing density result in larger soybeans containing higher protein and oil contents and a reduced number of greenish soybeans? Does narrower row spacing promote better environmental resource usage and a consequent increased production of larger soybeans with lower percentages of greenish soybeans and higher oil and protein contents? On the basis of currently available information, this study aimed to evaluate the effects of row spacing and sowing density on soybean size and the influence of these factors on chlorophyll retention and protein and oil contents.

\section{Materials and Methods}

Two experiments were conducted during the 2013/14 and 2014/15 growing seasons at the Embrapa Soja experimental farm, located in Londrina - PR, Brazil $\left(23^{\circ} 11^{\prime} \mathrm{S}, 51^{\circ} 11^{\prime} \mathrm{W}\right.$; altitude: $620 \mathrm{~m}$ ), using the same experimental area in both seasons. Local soil type has been identified as a Latossolo Vermelho distroférrico (SANTOS et al., 2006), and had the following attributes within the $0-20 \mathrm{~cm}$ soil layer prior to experimental implementation: organic carbon $=21.4 \mathrm{~g} \mathrm{dm}^{-3}$; $\mathrm{pH}\left(\mathrm{CaCl}_{2}\right)=4.9 ; \mathrm{P}=8.6 \mathrm{mg} \mathrm{dm}{ }^{-3} ; \mathrm{K}=0.55 \mathrm{cmol}_{\mathrm{c}}$ $\mathrm{dm}^{-3} ; \mathrm{Ca}=3.7 \mathrm{cmol}_{\mathrm{c}} \mathrm{dm}^{-3} ; \mathrm{Mg}=1.4 \mathrm{cmol}_{\mathrm{c}} \mathrm{dm}^{-3}$; and $55 \%$ CEC base saturation.

Local plant coverage was mechanically managed on the 11th day after sowing during both growing seasons using a shredder. Nine days after this operation, the remaining plants were chemically desiccated using glyphosate (1,080 ga.i. ha $\left.{ }^{-1}\right)$ and carfentrazone-ethyl (30 ga.i. ha $\left.{ }^{-1}\right)$. Non-till planting was performed on October 30, 2013, over wheat straw, and on November 12, 2014, over black oat straw; the average sowing speed was $5 \mathrm{~km} \mathrm{~h}^{-1}$, for which a planter was used (SHM 11/13, Semeato, Passo Fundo - RS, Brazil). Seeds were treated using Vitavax-Thiram 200SC ${ }^{\circledR}$ fungicide $\left(150 \mathrm{~mL} 50 \mathrm{~kg}^{-1}\right.$ seeds) and Gelfix $5^{\circledR}$ liquid inoculant $(100 \mathrm{~mL} 50$ $\mathrm{kg}^{-1}$ seeds). For these growth experiments, we used the BRS 359 RR cultivar, which has indeterminate growth, a relative maturity number of 6.0 , and plants with compact architecture.

Base dressing broadcast fertilization was performed 10 days prior to sowing, using $350 \mathrm{~kg} \mathrm{ha}^{-1}$ single superphosphate and $250 \mathrm{~kg} \mathrm{ha}^{-1}$ potassium chloride for the 2013/14 growing season, and $122 \mathrm{~kg} \mathrm{ha}^{-1}$ triple superphosphate and $250 \mathrm{~kg} \mathrm{ha}^{-1}$ potassium chloride for the 2014/15 growing season. Disease, pest, and weed control were performed in accordance with recommended techniques for soybean (EMBRAPA, 2011). Plot dimensions were $10 \mathrm{~m}$ (length) $\times 5 \mathrm{~m}$ (width), comprising a 50.0 $\mathrm{m}^{2}$ area. Harvest was performed using a combine harvester on the five central plot lines, and the harvested area was $15 \mathrm{~m}^{2}(10 \mathrm{~m}$ length $\times 1.5 \mathrm{~m}$ width). Harvesting was performed during the $\mathrm{R} 8$ stage, with no delays, and the combine was adjusted in order to reduce mechanical damage. Rainfall, and minimum, average, and maximum air temperatures for the experimental period are presented in Figures $1 \mathrm{~A}$ and $1 \mathrm{~B}$.

During the first experimental stage, a $4 \times 3$ factorial randomized block design was used, with three repetitions. Treatments comprising four different row spacing widths[20 $\mathrm{cm}$ (reduced), 50 $\mathrm{cm}$ (conventional), 20/80 cm (double-row), and 50 $\mathrm{cm}$ (cross-row)] and three sowing densities [150, 300 (recommended for the used cultivar), and 450 thousand feasible seeds $\mathrm{ha}^{-1}$ ] were used. These sowing densities provided the following respective plant densities: 140, 260, and 390 thousand plants $\mathrm{ha}^{-1}$ for the 2013/14 growing season, and 170, 310 , and 475 thousand plants $\mathrm{ha}^{-1}$ for the $2014 / 15$ growing season. 
Figure 1. Rainfall $(\mathrm{mm})$, and minimum, average, and maximum air temperatures $\left({ }^{\circ} \mathrm{C}\right)$ by ten days-months, during the experimental period. Londrina - PR, 2013/14 (A) and 2014/15 (B) growing seasons.
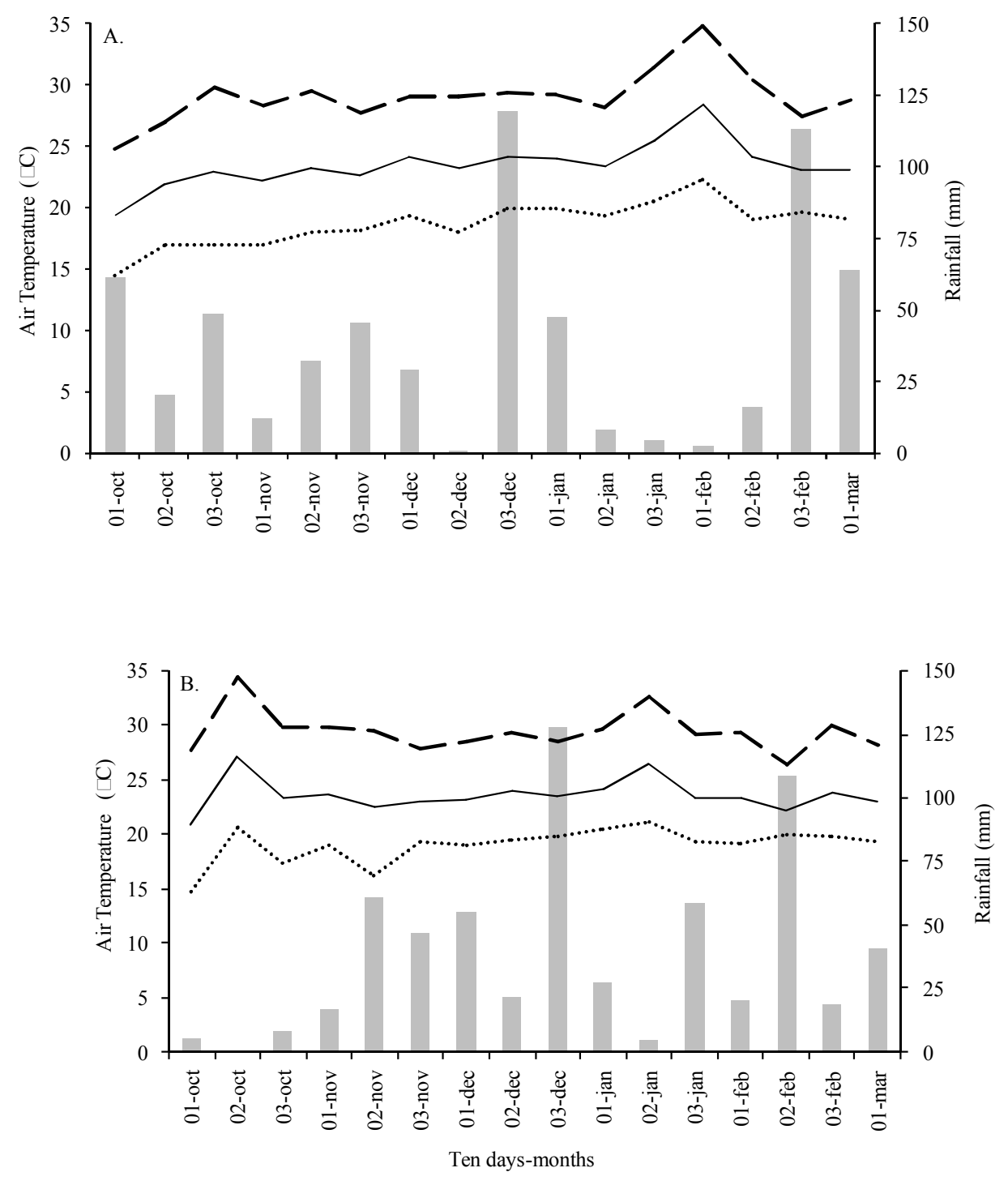

Rainfall (mm)

- Average air temperature $\left({ }^{\circ} \mathrm{C}\right)$

Minimum air temperature $\left({ }^{\circ} \mathrm{C}\right)$

- Maximum air temperature $\left({ }^{\circ} \mathrm{C}\right)$

Soybeans were harvested and cleaned, and then packed in multi-layer paper bags. Subsequently, 2-kg samples from each plot were classified using sieves, the mesh sizes of which differed between the two growing season, depending on soybeans size. The following oblong sieves were used: $10 \times 3 / 4$ " $(3.97 \times 19.05 \mathrm{~mm}), 11 \times 3 / 4$ " $(4.36 \times 19.05 \mathrm{~mm})$, $12 \times 3 / 4$ " $(4.76 \times 19.05 \mathrm{~mm})$, and $13 \times 3 / 4$ " $(5.16 \times$ $19.05 \mathrm{~mm}$ ) for the $2013 / 14$ growing season, and 12 $\times 3 / 4$ ", $13 \times 3 / 4$ ", $14 \times 3 / 4$ " $(5.56 \times 19.05 \mathrm{~mm}), 15 \times$ $3 / 4$ " $(5.95 \times 19.05 \mathrm{~mm})$, and $16 \times 3 / 4$ " $(6.35 \times 19.05$ $\mathrm{mm}$ ) for the $2014 / 15$ growing season. One thousand grain mass was determined using each sieve.

During the second experimental stage, a $4 \times 3$ $\times 4$ factorial randomized block design was used (four row spacing widths, three sowing densities, and four sieves) for the 2013/14 growing season, and a $4 \times 3 \times 5$ design (four row spacing widths, 
three sowing densities, and five sieves) for the 2014/15 growing season. The following evaluations were individually performed for each sieve size: percentage of greenish soybeans, and protein and oil contents. Soybeans were considered greenish when showing any extent of greenish tegumental color. In order to standardize the classification, identification of greenish beans was performed by the same evaluators. The one thousand bean mass determinations were performed by counting and subsequent weighing of one thousand grains from each subsample.

The protein and oil contents of samples were determined for intact grains using near infrared (NIR) spectroscopy, as described by Heil (2010). Intact and clean grains from each sample were submitted to measurements using an FT-NIR analyzer (Antaris II; Thermo Fisher Scientific, Waltham, USA) equipped with a $4 \mathrm{~cm}^{-1}$ spectral resolution integrating sphereand background at each measurement, at 32 scans. Prediction was performed using mathematic models described by Embrapa Soja (2011/12) for protein [180 patterns; correlation coefficient (r) $=0.97 \mathrm{~m}$; and Root Mean Square Deviation of Calibration $(\mathrm{RMSEC})=0.64]$ and oil contents $(170$ patterns; $r=0.98$; and $\mathrm{RMSEC}=0.45$ ).

The data obtained was submitted to variance analysis and means were compared using Tukey's test at 5\% probability. Analyses were performed using SISVAR (Sistema para Análise de Variância) software (FERREIRA, 2011).

\section{Results and Discussion}

The average one thousand grain mass for the 2013/14 growing season for $10 \times 3 / 4$ ", $11 \times 3 / 4$ ", $12 \times 3 / 4$ ", and $13 \times 3 / 4 "$ sieves was $92.3,107.4$, 123.8 , and $144.3 \mathrm{~g}$, respectively. For the 2014/15 growing season, the average one thousand grain mass for $12 \times 3 / 4$ ", $13 \times 3 / 4$ ", $14 \times 3 / 4$ ", $15 \times 3 / 4$ ", and $16 \times 3 / 4 "$ " sieves was $127.7,147.5,161.9,185.6$, and $217.6 \mathrm{~g}$, respectively. In neither growing season there was no interaction between of row spacing or sowing densities on soybean classification. For the 2013/14 growing season, a higher percentage of grains were classified by $12 \times 3 / 4$ " and $13 \times 3 / 4$ " sieves (larger soybeans) for $50-\mathrm{cm}$ row spacing, when compared with the other row spacings (Figure 2).There was no difference in soybean classification for remaining row spacing widths, and these tended to show higher percentages of soybeans classified as discard and small soybeans $(10 \times 3 / 4$ " sieve $)$, when compared to those obtained from plants with $50-\mathrm{cm}$ row spacing. Grains classified by the $11 \times$ $3 / 4$ " sieve (intermediate size) were not affected by row spacing. In the 2013/14 growing season, there was a significant water deficit associated with higher temperatures during soybean filling, from the second January ten days-months to the second February ten days-months (Figure 1A). Under these stress conditions, reduced row spacing and crossed planting probably promoted a higher loss of water through transpiration, which suppressed soybean development. In contrast, double-rows may have promoted higher water loss through evaporation, due to the lower soil coverage by canopies during the soybean filling stage, which limited plant development.

In the $2014 / 15$ growing season, the 20 -cm row spacing (reduced) produced a higher percentage of soybeans classified by $16 \times 3 / 4$ " sieves, when compared with the other row spacing widths (Figure 3). This can probably be explained by the lower plant equidistance obtained along the row by spacing reduction, which permitted rapid canopy coverage and higher sunlight interception, providing better conditions for soybean development during the filling stage. It is important to emphasize that meteorological conditions during the 2014/15 growing season were more favorable for soybean filling, compared with those in the 2013/14 growing season (Figure 1B). There was no difference among the evaluated row spacing widths with regards to grains classified as discard or by other sieves. 
Figure 2. Percentages of soybeans classified by $10 \times 3 / 4$ ", $11 \times 3 / 4$ ", $12 \times 3 / 4$ ", and $13 \times 3 / 4$ " sieves for four row spacing widths (means of three sowing densities). Londrina - PR, Brazil, 2013/14 growing season.

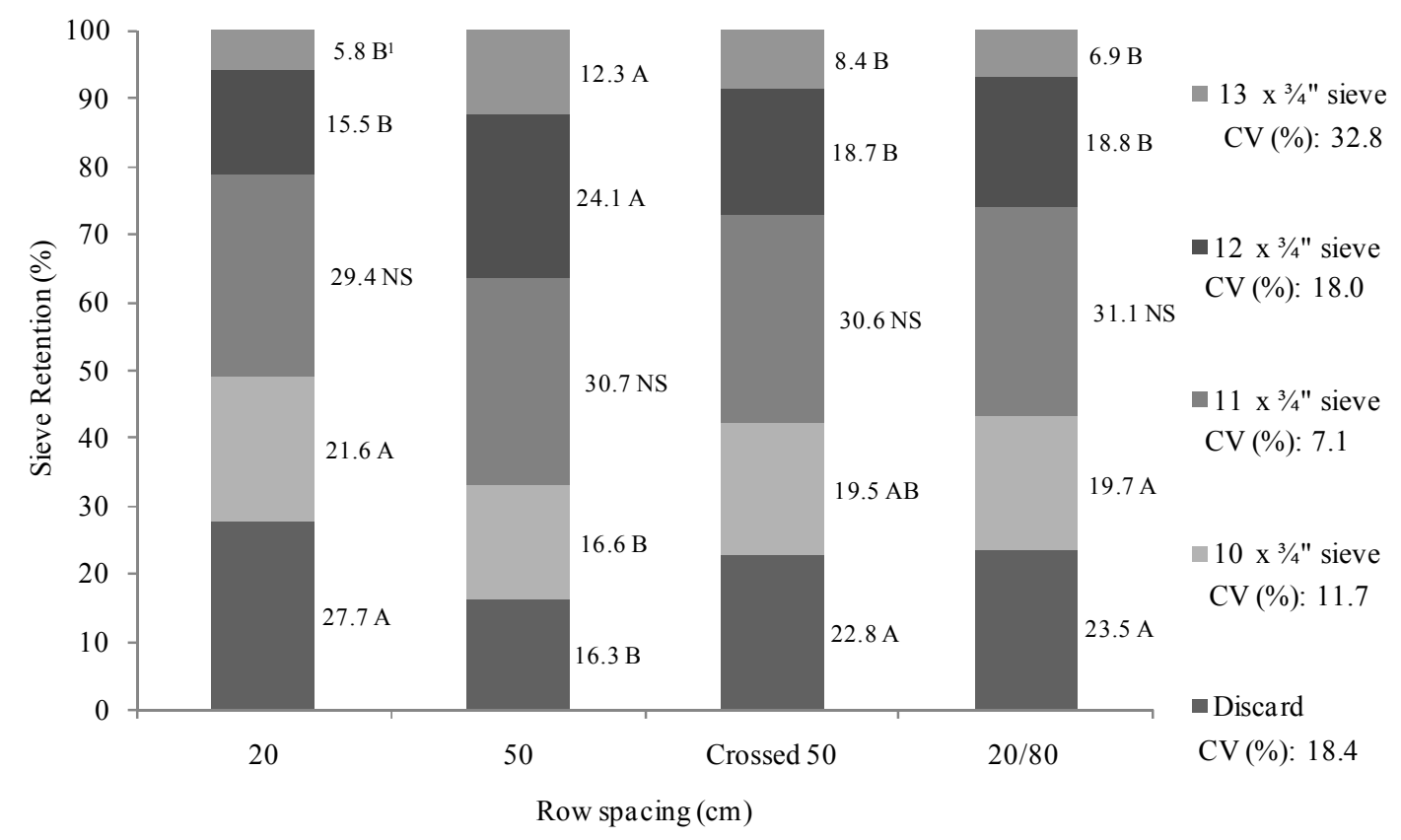

${ }^{1}$ Means followed by the same letter for each sieve do not differ by Tukey's test at $5 \%$ probability.

Figure 3. Percentages of soybeans classified by $12 \times 3 / 4$ ", $13 \times 3 / 4$ ", $14 \times 3 / 4$ ", $15 \times 3 / 4$ ", and $16 \times 3 / 4$ " sieves, for four row spacing widths (means of three sowing densities). Londrina-PR, Brazil, 2014/15 growing season.

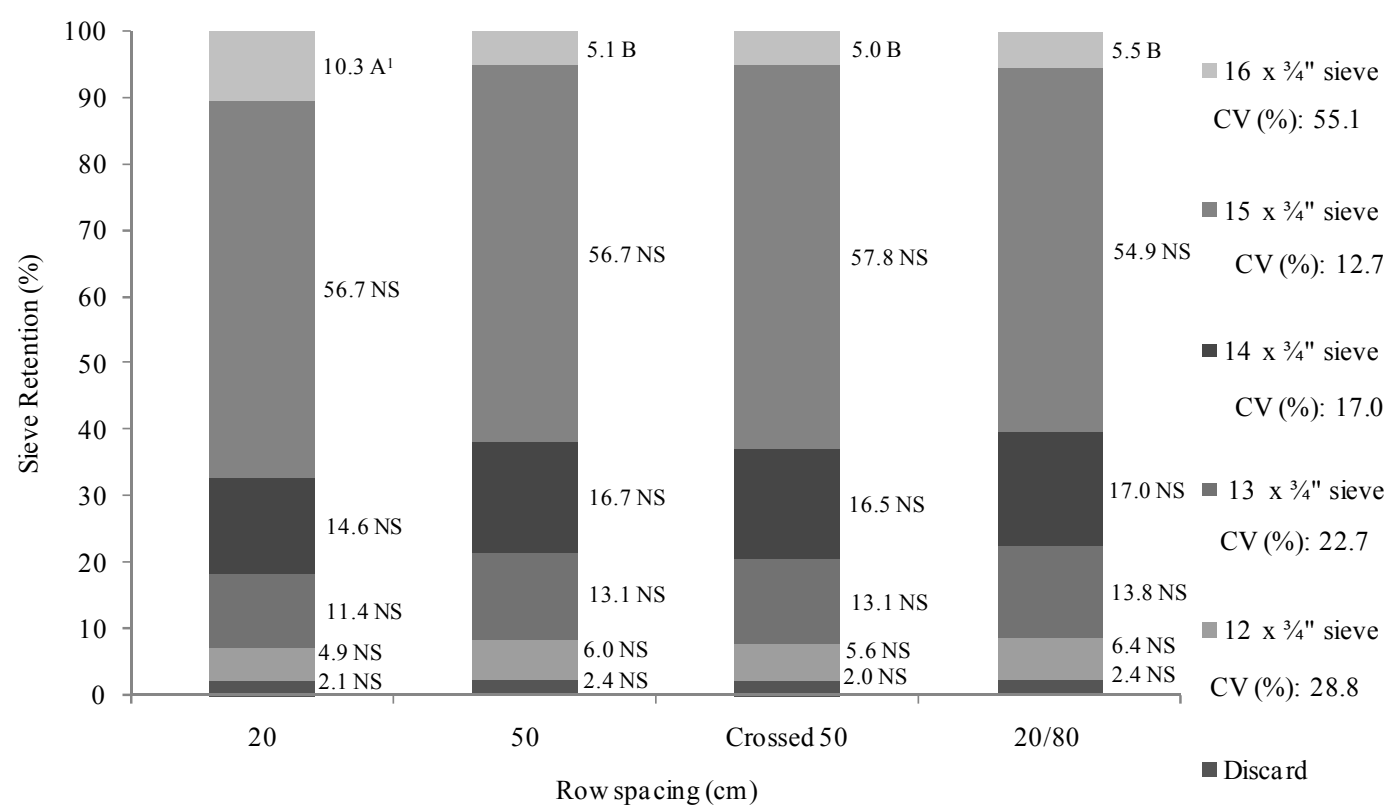

${ }^{1}$ Means followed by the same letter for each sieve do not differ by Tukey's test at $5 \%$ probability. 
In the 2013/14 growing season, there were no differences between sowing densities of 300 and 450 thousand feasible seeds $\mathrm{ha}^{-1}$ in terms of the percentage of grains classified by different sieves (Figure 4). However, these densities produced higher percentages of soybeans classified by $12 \times$ $3 / 4$ " and $13 \times 3 / 4$ " sieves, and lower percentages of grains classified as discard and by the $10 \times 3 / 4$ " sieve, when compared to a sowing density of 150 feasible seeds $\mathrm{ha}^{-1}$. This difference can probably be attributed to the growth of deeper roots resulting from the higher intraspecific competition at higher plant densities (CRAINE; DYBZINSKI, 2013).This provided better conditions for water absorption in deeper soil layers during the soybean filling stages, during which a significant water deficit occurred. Furthermore, higher sowing densities result in lower numbers of pods per plant and higher stem contribution to soybean production, which promotes a higher demand for photoassimilates, at the expense of that of branches, and facilitates the development of larger grains (BALBINOT JR. et al., 2015). Kuss et al. (2008) also observed larger grains associated with higher plant density, particularly during water deficit periods occurring during the grain formation period. Similar to the observations for row spacing, grains classified by the $11 \times 3 / 4$ " sieve (intermediate size) were also unaffected by plant density.

Figure 4. Percentages of soybeans classified by $10 \times 3 / 4$ ", $11 \times 3 / 4$ ", $12 \times 3 / 4$ ", and $13 \times 3 / 4$ " sieves for three sowing densities (means of four row spacing widths). Londrina-PR, Brazil, 2013/14growing season.

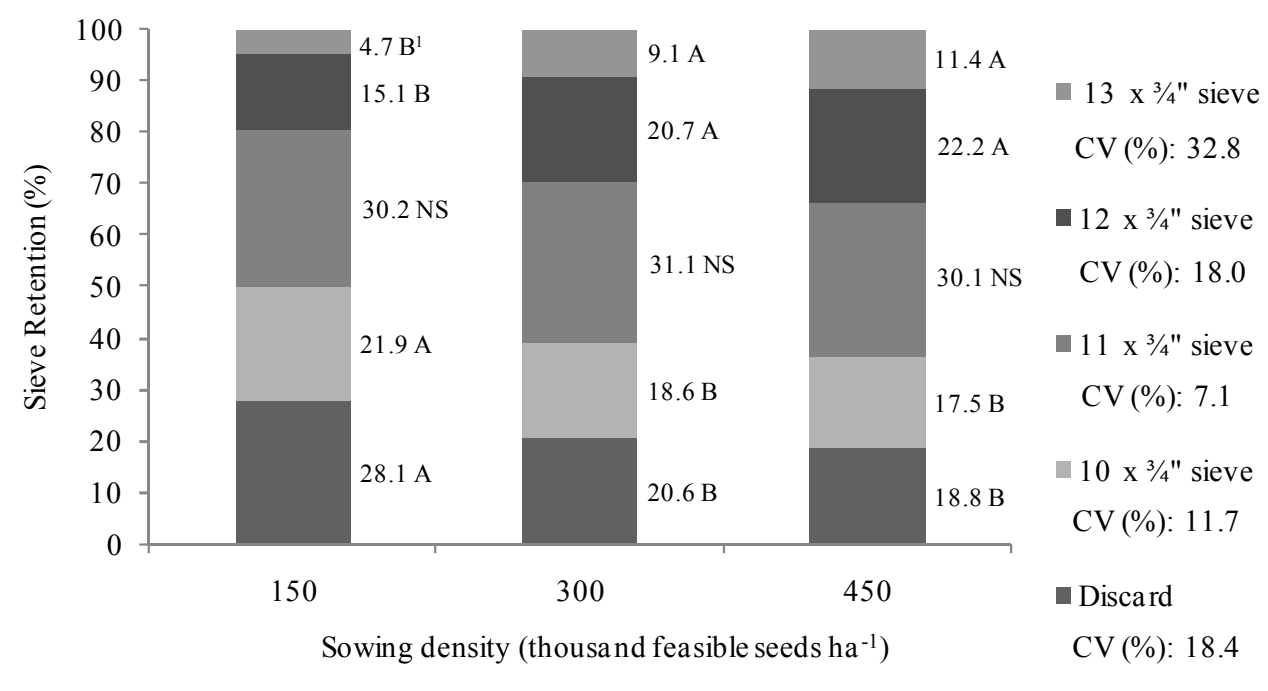

${ }^{1}$ Means followed by the same letter for each sieve do not differ by Tukey's test at $5 \%$ probability.

In the absence of stress, the effects of sowing density on grain size were greater when compared with the effects of row spacing, which can probably be attributed to the fact that density is a more important restrictive factor for plant growth and development than is row spacing (Figure 5). In the 2014/15 growing season, a sowing density of 150 thousand feasible seeds $\mathrm{ha}^{-1}$ produced a higher percentage of grains classified as discard or by 12 $\times 3 / 4$ ", $13 \times 3 / 4$ ", and $14 \times 3 / 4$ " sieves, and lower percentages of seeds classified by $15 \times 3 / 4$ " and 16 $\times 3 / 4$ " sieves, when compared with higher sowing densities, and particularly with the sowing density of 450 thousand feasible seeds $\mathrm{ha}^{-1}$. In contrast to row spacing, the effects of sowing density on the percentage of grains classified by sieves were similar under both stress and non-stress conditions (Figures 4 and 5). In this regard, seed production farms should avoid sowing densities below the recommended, because although this promotes 
higher numbers of pods per plant (BALBINOT JR. et al., 2015), the soybeans may be smaller, which may impair quality and, consequently, trade.

In the 2013/14 growing season, row spacing, sowing densities, and soybeans size generally did not affect the percentage of greenish soybeans produced; however, spacing and density did affect this parameter in an isolated manner. Crossed 50- $\mathrm{cm}$ row spacing, as well as a sowing density of 450 thousand feasible seed ha-1 ${ }^{-1}$ promoted a higher percentage of greenish soybeans, when compared with the other evaluated row spacing widths and sowing densities (Table 1). However, it is worth emphasizing that differences in the percentages of greenish soybeans among sowing densities were small (approximately 3\%, absolute value) under water stress conditions.

Figure 5. Percentages of soybeans classified by $12 \times 3 / 4$ ", $13 \times 3 / 4$ ", $14 \times 3 / 4$ ", $15 \times 3 / 4$ ", and $16 \times 3 / 4$ " sieves for three sowing densities (means of four row spacing widths). Londrina-PR, Brazil, 2014/15 growing season.

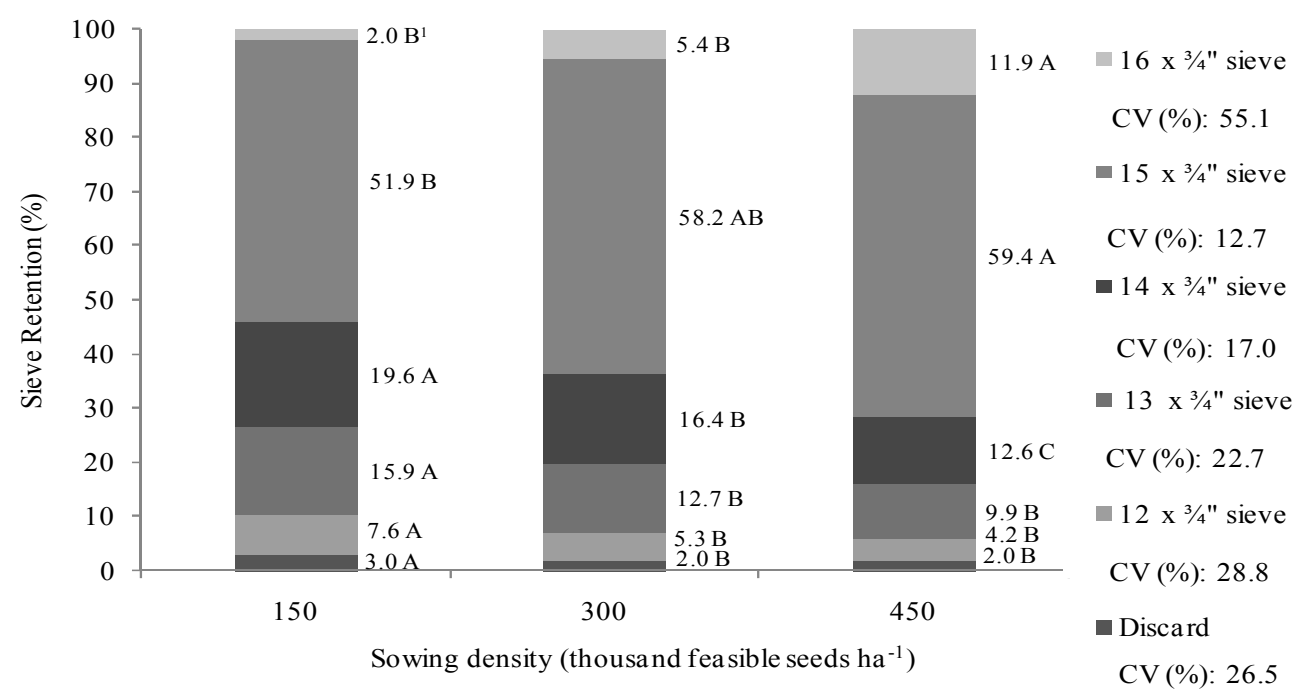

${ }^{1}$ Means followed by the same letter for each sieve do not differ by Tukey's test at $5 \%$ probability.

Table 1. Percentage of greenish soybeans depending on sowing densities (means of four row spacing widths and four sieves) and row spacing widths (means of three sowing densities and four sieves). Londrina-PR, Brazil, 2013/14 growing season.

\begin{tabular}{cc}
\hline Density (thousand feasible seeds $\mathrm{ha}^{-1}$ ) & Greenish Soybeans (\%) \\
\hline 150 & $10.52 \mathrm{~B}^{1}$ \\
300 & $10.67 \mathrm{~B}$ \\
450 & $13.57 \mathrm{~A}$ \\
\hline Row spacing $(\mathrm{cm})$ & \\
\hline 20 & $11.05 \mathrm{~B}$ \\
50 & $10.94 \mathrm{~B}$ \\
Crossed 50 & $15.52 \mathrm{~A}$ \\
$20 / 80$ & $8.83 \mathrm{~B}$ \\
\hline $\mathrm{CV}(\%)$ & 38.8 \\
\hline
\end{tabular}

${ }^{1}$ Means followed by the same capital letter in columns do not differ by Tukey's test ( $\left.\mathrm{p} \leq 0.05\right)$. 
In the 2014/15 growing season, no greenish soybeans were observed, which could be attributed to a better rainfall distribution and mild temperatures during the soybean filling stage. Thus, favorable conditions for soybean development occurred among all treatments. In this case, chlorophyll levels were lower due to uninterrupted chlorophyllase activity. Chlorophyll degradation begins with hydrolysis of the phytol group, resulting in chlorophyllide (green), which is more soluble in water than chlorophyll. Subsequently, pheophorbide is formed due to loss of thephytol group and $\mathrm{Mg}^{+2}$, giving rise toa greenbrown color.Thereafter, oxidative transformations occurs, generating colorless degradation products, which result in the transition from a greenish color to the normal yellowish color of mature soybeans (PÁDUA et al., 2009; RANGEL et al., 2011). Thus, the effects of meteorological conditions on the incidence of this physiological problem was evidenced.
In the 2013/14 growing season, there was no effect of sieve classification on protein and oil contents; however, row spacing and densities affected these soybean characteristics. Higher protein content $(37.48 \%)$ was obtained with a 50 $\mathrm{cm}$ row spacing (conventional) and with the highest sowing density (450 thousand feasible seeds ha-1), and this value did not differ statistically from those obtained with crossed 50-cm spacing and 20/80$\mathrm{cm}$ double row spacing (Table 2). Row spacing of $50 \mathrm{~cm}$ combined with 300 thousand feasible seeds ha ${ }^{-1}$ produced the highest oil content (23.95\%); however, this value did not differ statistically from that obtained with 20-cm (reduced) and 20/80-cm (double row) spacing. In contrast to these findings, Moreira et al. (2015) observed no effects of different row spacing widths and sowing densities on oil and protein contents. In general, crossed $50-\mathrm{cm}$ row spacing produced the highest protein and the lowest oil contents, thus revealing the negative correlation between these soybean components (CLEMENTE; CAHOON, 2009; PINHEIRO et al., 2013).

Table 2. Percentage of protein and oil in soybeans with four row spacing widths and three sowing densities (means of four sieves). Londrina-PR, Brazil, 2013/14 growing season.

\begin{tabular}{|c|c|c|c|c|}
\hline \multirow{3}{*}{$\begin{array}{c}\text { Density } \\
\text { (thousand feasible seeds ha-1) }\end{array}$} & \multicolumn{4}{|c|}{ Row spacing $(\mathrm{cm})$} \\
\hline & 20 & 50 & Crossed 50 & $20 / 80$ \\
\hline & \multicolumn{4}{|c|}{ Protein $(\%)$} \\
\hline 150 & $35.49 \mathrm{abA}^{1}$ & $35.87 \mathrm{abB}$ & $37.10 \mathrm{aA}$ & $35.19 \mathrm{bA}$ \\
\hline 300 & $35.50 \mathrm{bA}$ & $34.67 \mathrm{bB}$ & $37.37 \mathrm{aA}$ & $35.28 \mathrm{bA}$ \\
\hline 450 & $35.67 \mathrm{bA}$ & $37.48 \mathrm{aA}$ & $36.37 \mathrm{abA}$ & $36.23 \mathrm{abA}$ \\
\hline \multirow{2}{*}{$\mathrm{CV}(\%)$} & \multicolumn{4}{|c|}{4.7} \\
\hline & \multicolumn{4}{|c|}{ Oil (\%) } \\
\hline 150 & $23.62 \mathrm{aA}$ & $22.70 \mathrm{abB}$ & $21.86 \mathrm{bA}$ & $23.37 \mathrm{aA}$ \\
\hline 300 & $23.19 \mathrm{abA}$ & $23.95 \mathrm{aA}$ & $22.39 \mathrm{bA}$ & $23.35 \mathrm{abA}$ \\
\hline 450 & $23.01 \mathrm{aA}$ & $21.94 \mathrm{aB}$ & $22.65 \mathrm{aA}$ & $22.55 \mathrm{aA}$ \\
\hline $\mathrm{CV}(\%)$ & \multicolumn{4}{|c|}{4.5} \\
\hline
\end{tabular}

${ }^{1}$ Means followed by the same capital letter in columns and the same letter in rows do not differ by Tukey's test $(\mathrm{p} \leq 0.05)$.

In the 2014/15 growing season,there was no interaction between the studied factors and the protein and oil contents of soybeans. The three evaluated factors had inconsistent effects on protein content. Soybeans produced under $20-\mathrm{cm}$ row spacing had the highest protein content, when compared with the contents obtained with the other evaluated row spacing widths (Table 3). Similarly, higher sowing density produced soybeans with higher protein contents. Bellaloui et al. (2014) 
studied different soybean spatial arrangements and observed that higher sowing densities resulted in higher protein content, however, these results were obtained only under water stress conditions and high temperatures. Furthermore, higher protein content was observed for larger soybeans (Table 3). The protein content difference among grains classified by $12 \times 3 / 4$ " and $16 \times 3 / 4$ " sieves was approximately $2 \%$, which is a significant value for protein meal production for animal feeds. Oil content was not affected by the evaluated experimental factors, thus, it appears that this is a variable that is little affected by environmental conditions (DARDANELLI et al., 2006; GAO et al., 2009; MAEHLER et al., 2003).

Table 3. Percentages of protein and oil in soybeans, in four row spacing widths, three sowing densities, and five sieves. Londrina-PR, Brazil, 2014/15growing season.

\begin{tabular}{ccc}
\hline Row spacing $(\mathrm{cm})$ & Protein $(\%)$ & Oil $(\%)$ \\
\hline 20 & $39.53 \mathrm{~A}^{1}$ & $22.00 \mathrm{~A}$ \\
50 & $38.93 \mathrm{~B}$ & $22.31 \mathrm{~A}$ \\
Crossed 50 & $39.29 \mathrm{AB}$ & $21.91 \mathrm{~A}$ \\
$20 / 80$ & $38.86 \mathrm{~B}$ & $22.18 \mathrm{~A}$ \\
\hline Density & & \\
\hline 150 & $38.86 \mathrm{~B}$ & $22.18 \mathrm{~A}$ \\
300 & $39.04 \mathrm{~B}$ & $22.02 \mathrm{~A}$ \\
(thousand feasible seeds ha-1) $\left.^{-1}\right)$ & $39.56 \mathrm{~A}$ & $22.11 \mathrm{~A}$ \\
\hline Sieves & & \\
\hline $12 \times 3 / 4 "$ & $38.41 \mathrm{C}$ & $22.13 \mathrm{~A}$ \\
$13 \times 3 / 4 "$ & $38.63 \mathrm{C}$ & $22.26 \mathrm{~A}$ \\
$14 \times 3 / 4 "$ & $38.76 \mathrm{C}$ & $22.25 \mathrm{~A}$ \\
$15 \times 3 / 4 ”$ & $39.56 \mathrm{~B}$ & $22.08 \mathrm{~A}$ \\
$16 \times 3 / 4 "$ & $40.41 \mathrm{~A}$ & $21.78 \mathrm{~A}$ \\
\hline CV $(\%)$ & 2.3 & 3.6 \\
\hline
\end{tabular}

${ }^{1}$ Means followed by the same capital letter in columns do not differ by Tukey's test ( $\left.\mathrm{p} \leq 0.05\right)$.

\section{Conclusion}

Higher plant density promoted the development of larger soybeans, whereas row spacing effects on bean size varied between the different growing seasons.

A cross-row arrangement and higher plant density resulted in an increased percentage of greenish beans, under meteorological conditions favorable for the development of this characteristic.

Spatial arrangement effects on soybean protein and oil contents were variable, and thus it was not possible to determine a spatial arrangement that promotes increments of soybean protein or oil contents.
Larger soybeans have higher protein content; however, oil content is not affected by soybean size.

\section{Acknowledgements}

We would like to thank the Coordination for the Improvement of Higher Education Personnel (CAPES), the State University of Londrina, and the Brazilian Agricultural Research Corporation (EMBRAPA) for the facilities and financial aid provided for developing this study. We are also grateful to the National Council for Scientific and Technological Development (CNPq) for granting the second author with a "Productivity 
for Technological Development and Innovative Extension" fellowship program.

\section{References}

ÁVILA, M. R.; BRACCINI, A. L.; SCAPIM, C. A.; MANDARINO, J. M. G.; ALBRECHT, L. P.; VIDIGAL FILHO, P. S. Componentes do rendimento, teores de isoflavonas, proteínas, óleo e qualidade de sementes de soja. Revista Brasileira de Sementes, Londrina, v. 29, n. 3, p. 111-127, 2007.

BALBINOT JUNIOR, A. A.; PROCÓPIO, S. O.; DEBIASI, H.; FRANCHINI, J. C.; PANISON, F. Semeadura cruzada em cultivares de soja com tipo de crescimento determinado. Semina: Ciências Agrárias, Londrina, v. 36, n. 3, p. 1215-1226, 2015.

BELlALOUI, N.; BRUNS, H. A.; ABBAS, H. K.; MENGISTU, A.; FISHER, D. K.; REDDY, K. N. Agricultural practices altered soybean seed protein, oil, fatty acids, sugars, and minerals in the Midsouth USA. Frontiers in Plant Science, Lausanne, v. 31, n. 6, p. 1-14, 2015.

BELLALOUI, N.; MENGISTU, A.; WALKER, E. R.; YOUNG, L. D. Soybean seed composition as affected by seeding rates and row spacing. Crop Science, Madison, v. 54, n. 4, p. 1782-1795, 2014.

BOARD, J. Light interception efficiency and light quality affect yield compensation of soybean at low plant populations. Crop Science, Madison, v. 40, n. 5, p. 1285 1294, 2000.

BOROOMANDAM, P.; KHORAMIVAFA, M.; HAGHI, Y.; EBRAHIMI, A. The effects of nitrogen starter fertilizer and plant density on yield, yield components and oil and protein content of soybean (Glycine max L. Merr.). Pakistan Journal of Biological Sciences, Dubai, v. 12, n. 4, p. 378-382, 2009.

CLEMENTE, T. E.; CAHOON, E. B. Soybean oil: genetic approaches for modification of functionality and total content. Plant Physiology, Rockville, v. 151, n. 3, p. 1030-1040, 2009.

CRAINE, J. M.; DYBZINSKI, R. Mechanisms of plant competition for nutrients, water and light. Functional Ecology, London, v. 27, n. 4, p. 833-840, 2013.

DARDANELLI, J. L.; BALZARINI, M.; MARTINEZ, M. J.; CUNIBERTI, M.; RESNIK, S.; RAMUNDA, S. F.; HERRERO, R.; BAIGORRI, H. Soybean maturity groups, environments, and their interaction define megaenvironments for seed composition in Argentina. Crop Science, Madison, v. 46, n. 5, p. 1939-1947, 2006.
EMPRESA BRASILEIRA DE PESQUISA AGROPECUÁRIA - EMBRAPA. Tecnologias de produção de soja - Região Central do Brasil 2012 e 2013. 21. ed. Londrina: Embrapa Soja, 2011. 261p.

FERREIRA, D. F. Sisvar: a computer statistical analysis system. Ciência e Agrotecnologia, Lavras, v. 35, n. 6, p. 1039-1042, 2011.

FRANÇA-NETO, J. B.; PÁDUA, G. P.; KRZYZANOWSKI, F. C. Semente esverdeada de soja: causas e efeitos sobre o desempenho fisiológico - Série Sementes. Londrina: Embrapa Soja, 2012. (Embrapa Soja, Circular técnica, 91).

GAO, J.; HAO, X.; THELEN, K. D.; ROBERTSON, G. P. Agronomic management system and precipitation effects on soybean oil and fatty acid profiles. Crop Science, Madison, v. 49, n. 1, p. 1049-1057, 2009.

HEIL, C. Rapid, multi-component analysis of soybeans by FT-NIR Spectroscopy. Madison: Thermo Fisher Scientific, 2010. 3 p. (Application note: 51954). Available at: $\quad<$ https://www.thermoscientific.com/content/dam/ tfs/ATG/CMD/CMD\%20Documents/Application\%20 \&\%20Technical\%20Notes/AN-51954-Rapid-MultiComponent-Analysis-Soybeans-AN51954-EN.pdf>. Accessed at: 2 jul. 2016.

KHAN, A. Z.; SHAH, P.; KHALIL, S. K.; TAJ, F. $\mathrm{H}$. Influence of planting date and plant density on morphological traits of determinate and indeterminate soybean cultivars under temperate environment. Pakistan Journal of Agronomy, Faisalabad, v. 2, n. 3, p. 146-152, 2003.

KUSS, R. C. P.; KONIG, O.; DUTRA, L. M. C.; BELLÉ, R. A.; ROGGIA, S.; STURMER, G. R. Populações de plantas e estratégias de manejo de irrigação na cultura da soja. Ciência Rural, Santa Maria, v. 38, n. 4, p. 11331137, 2008.

LUCA, M. J.; HUNGRIA, M. Plant densities and modulation of symbiotic nitrogen fixation in soybean. Scientia Agricola, Piracicaba, v. 71, n. 3, p. 181-187, 2014.

MAEHLER, A. R.; COSTA, J. A.; PIRES, J. L. F.; RAMBO, L. Qualidade de grãos de duas cultivares de soja em função da disponibilidade de água no solo e arranjo de plantas. Ciência Rural, Santa Maria, v. 33, n. 2, p. 213-218, 2003.

MINUZZI, A.; RANGEL, M. A. S.;BRACCINI, A. L.; SCAPIM, C. A.; MORA, F.; ROBAINA, A. D. Rendimento de teores de óleo e proteínas de quatro cultivares de soja, produzidas em dois locais no estado do Mato Grosso do Sul. Ciência e Agrotecnologia, Lavras, v. 33, n. 4, p. 80-93, 2009. 
MOREIRA, A.; MORAES, L. A. C.; SCHROTH, G.; MANDARINO, J. M. G. Effect of nitrogen, row spacing, and plant density on yield, yield components, and plant physiology in soybean-wheat intercropping. Agronomy Journal, Madison, v. 107, n. 6, p. 2162-2170, 2015.

MOURTZINIS, S.; GASKA, J. M.; PEDERSEN, P.; CONLEY, S. P. Effect of seed mass and emergence delay on soybean yield and quality. Agronomy Journal, Madison, v. 107, n. 1, p. 181-186, 2015.

PÁDUA, G. P.; CARVALHO, M. L. M.; FRANÇANETO, J. B.; GUERREIRO, M. C.; GUIMARÃES, R. $M$. Response of soybean genotypes to the expression of green seed under temperature and water stresses. Revista Brasileira de Sementes, Londrina, v. 31, n. 3, p. 140-149, 2009.

PINHEIRO, L. C. M.; GOD, P. I. V. G.; FARIA, V. R.; OLIVEIRA, A. G.; HASUI, A. A.; PINTO, E. H. G.; ARRUDA, K. M. A.; PIOVESAN, N. D.; MOREIRA, M. A. Parentesco na seleção para produtividade e teores de óleo e proteína em soja via modelos mistos. Pesquisa Agropecuária Brasileira, Brasília, v. 48, n. 9, p. 12461253, 2013.

PROCÓPIO, S. O.; BALBINOT JUNIOR, A. A.; DEBIASI, H.; FRANCHINI, J. C.; PANISON, F. Plantio cruzado na cultura da soja utilizando uma cultivar de hábito de crescimento indeterminado. Revista de Ciências Agrárias/Amazonian Journal of Agricultural and Environmental Sciences, Belém, v. 56, n. 4, p. 319$325,2013$.

RANGEL, M. A. S.; MINUZZI, A.; PÌEREZAN, L.; TEODÓSIO, T. K. C.; ONO, F. B.; CARDOSO, P. C. Presença e qualidade de sementes esverdeadas de soja na região sul do Estado do Mato Grosso do Sul. Acta Scientiarum Agronomy, Maringá, v. 33, n. 1, p. 127-132, 2011.

RIGSBY, B.; BOARD, J.E. Identification of soybean cultivars that yield well at low plant populations. Crop Science, Madison, v. 43, n.1, p. 234-23, 2003.

SANTOS, H. G.; JACOMINE, P. K. T.; ANJOS, L. H. C.; OLIVEIRA, V. A.; OLIVEIRA, J.B.; COELHO, M. R.; LUMBRERAS, J.F.; CUNHA, T. J. F. Sistema brasileiro de classificação de solos. 2. ed. Rio de Janeiro: Embrapa Solos, 2006. 306 p.

YIN, X.; VYN, T. J. Relationships of isoflavone, oil, and protein in seed with yield of soybean. Agronomy Journal, Madison, v. 97, n. 5, p. 1314-1321, 2005.

ZAKIR.M, M.; FREITAS.I, R. Benefícios à saúde humana do consumo de isoflavonas presentes em produtos derivados da soja. Journal of Bioenergy and Food Science, Macapá, v. 2, n. 3, p. 107-116, 2015. 